\title{
Effects of zinc ex vivo on taurine uptake in goldfish retinal cells
}

\author{
Sonia Nusetti, Mary Urbina, Lucimey Lima* \\ From $17^{\text {th }}$ International Meeting of Taurine \\ Fort Lauderdale, FL, USA. 14-19 December 2009
}

\begin{abstract}
Background: Taurine and zinc exert neurotrophic effects in the central nervous system. Current studies demonstrate that $\mathrm{Na}^{+} / \mathrm{Cl}^{-}$dependent neurotransmitter transporters, similar to that of taurine, are modulated by micromolar concentrations of zinc. This study examined the effect of zinc sulfate ex vivo on $\left[^{3} \mathrm{H}\right]$ taurine transport in goldfish retina.

Methods: Isolated cells were incubated in Ringer with zinc (0.1-100 $\mu \mathrm{M})$. Taurine transport was done with $50 \mathrm{nM}$ $\left[{ }^{3} \mathrm{H}\right]$ taurine or by isotopic dilution with taurine $(0.001-1 \mathrm{mM})$ and $50 \mathrm{nM}\left[{ }^{3} \mathrm{H}\right]$ taurine.

Results: Zinc reduced the capacity of taurine transport without changes in affinity, and caused a noncompetitive inhibition of high affinity taurine transport, with an $\mathrm{EC}_{50}=0.072 \mu \mathrm{M}$. The mechanism by which zinc affects taurine transport is unknown at the present.

Conclusions: There may be a binding site of zinc in the transporter that affects union or translocation of taurine, or possibly the formation of taurine-zinc complexes, rather than free zinc, could affect the operation of the transporter.
\end{abstract}

\section{Background}

Taurine (2-aminoethane sulfonic acid), a $\beta$-amino acid that contains a negatively charged sulfonic acid group, is present at high levels in the retina of many vertebrates [1]. This amino acid is known to be involved in the mediation of multiple functions, such as osmoregulation, modulation of calcium fluxes, neuromodulation, protection from oxidative stress, modification of protein phosphorylation, membrane stabilization, affectation of cell migration in the brain and in the retina, regulation of axonal outgrowth, elevation in the number of regenerating retinal cells after nerve lesion, and production of neural protection in certain neuropathies [2-4]. Thus, taurine possesses neuroprotective and neurotrophic properties in the central nervous system (CNS) during development and regeneration. Some taurine functions

\footnotetext{
* Correspondence: llima@ivic.ve

Laboratorio de Neuroquímica, Centro de Biofísica y Bioquímica, Instituto

Venezolano de Investigaciones Científicas, Caracas, Venezuela

Full list of author information is available at the end of the article
}

are similar to those of zinc, an element with relevance in metabolic, genetic and neurotrofic processes $[5,6]$.

Zinc is highly concentrated in the retina [7]. The physiological functions of zinc have been studied in retina, where it is believed to interact with taurine, to modify photoreceptor plasma membranes, to modulate synaptic transmission and to serve as an antioxidant [8,9]. Zinc is essential for the normal development and function of the CNS and a deficiency of this element during early development can result in gross structural defects and pronounced behavioural abnormalities $[10,11]$. Experimental evidence demonstrates that zinc can have both positive and negative effects on the cells, depending on the local concentration or state of the cell. An excess of free zinc can be harmful and trigger in vitro as well as ex vivo neuronal damage [12-14]. The neuroprotective effect of low concentrations of zinc in the brain has been attributed to its antioxidant function and to the fact that zinc is an important modulator of excitatory synaptic transmission $[7,15]$. Zinc occurrence in cultures of goldfish retinal fragments at a concentration equal to
C Biomed Central

C 2010 Lima et al; licensee BioMed Central Ltd. This is an open access article distributed under the terms of the Creative Commons Attribution License (http://creativecommons.org/licenses/by/2.0), which permits unrestricted use, distribution, and reproduction in any medium, provided the original work is properly cited. 
or greater than $0.06 \mu \mathrm{M}$ in the presence of taurine reduces the amino acid trophic effect, which could be related to the interaction between both in the membranes or to the influence of zinc on taurine transport [16]. It has been demonstrated that micromolar concentrations of zinc modulate the activity of voltagedependent calcium channels, of receptors and of neurotransmitter transporters [17-20]. Taurine transporter, together with dopamine, norepinephrine and serotonin transporters, modulated by zinc, form a part of a subfamily within the large family of the $\mathrm{Na}^{+} / \mathrm{Cl}^{-}$-dependent transporters, all of which share the same topology of 12 transmembrane domains [21]. The trophic effect of taurine may be affected by the inhibition of its transport [22]; given that zinc, in concentrations equal to or greater than $0.06 \mu \mathrm{M}$, blocks the trophic function of this amino acid, that the effect of taurine could be influenced by transport inhibition, and that zinc modulates neurotransmitter transporters with the same topology, the evaluation of whether the presence or absence of zinc could affect taurine uptake was proposed as the objective of this work.

\section{Methods}

\section{Animals and preparation of cell suspension}

Goldfish (Carassius auratus), measuring $3-4 \mathrm{~cm}$, from a local commercial breeder (Fauna Roosevelt, Caracas, Venezuela), were kept in an aquarium in the Laboratory under 12:12-h light cycle for 1-3 weeks before use. The fish were dark adapted for $30 \mathrm{~min}$, which produces retraction of the retinal pigmented epithelium from the retina, and anesthetized with tricaine $(0.05 \%)$ prior to enucleation of the eye. The eyes were rinsed in Locke's solution free of $\mathrm{Ca}^{2+}$ and $\mathrm{Mg}^{2+}$ and the retina was dissected, placed in the same solution with trypsin and incubated at $25^{\circ} \mathrm{C}$ for $30 \mathrm{~min}$. The weight per retina was $30-35 \mathrm{mg}$ and contained 1-2 $\mathrm{mg}$ of total proteins. Mechanical dissociation was performed gently with a Pasteur pipette. After centrifugation at room temperature with a swinging rotor in a Damon/IEC Division centrifuge at $600 \mathrm{~g}$ for $5 \mathrm{~min}$, the pellet was washed and finally resuspended in Ringer solution $(\mathrm{NaCl} 125 \mathrm{mM}$, $\mathrm{KCl} 5 \mathrm{mM}, \mathrm{CaCl}_{2} 2 \mathrm{mM}, \mathrm{MgSO}_{4} 7 \mathrm{H}_{2} \mathrm{O} 1.3 \mathrm{mM}, \mathrm{Na}_{2} \mathrm{H}-$ $\mathrm{PO}_{4} \cdot 2 \mathrm{H}_{2} \mathrm{O} \quad 0.4 \mathrm{mM}, \mathrm{NaH}_{2} \mathrm{PO}_{4} 0.1 \mathrm{mM}, \mathrm{NaHCO}_{3}$ $25 \mathrm{mM}$, glucose $10 \mathrm{mM}$ ) [23].

\section{Kinetics of transport}

Initially, the uptake of $100 \mathrm{nM}\left[{ }^{3} \mathrm{H}\right]$ taurine (891.7 GBq/ $\mathrm{mmol}$ ) into total retinal cells was measured in a preparation of approximately 250,000 cells per tube for different periods of time: $0.5,2,4$, and 10 min to confirm the linearity of the uptake process. Also uptake of $100 \mathrm{nM}\left[{ }^{3} \mathrm{H}\right]$ taurine was determined in dilutions of cells preparations of 100, 200, 300 and 500,000 cells per test tube. The cell preparation was preincubated at $25^{\circ} \mathrm{C}$ for 2 min in Ringer solution. Uptake was initiated by adding $100 \mu \mathrm{l}$ of uptake buffer containing radiolabel substrate. After incubation, the process was stopped by rapid filtration through fibreglass filters (Watman GF/B), followed by two washes with $5 \mathrm{ml}$ of cold Ringer solution. The filters were placed in scintillation vials, dried, and counted in $4 \mathrm{ml}$ of toluene/omnifluor $0.04 \%$ in a Packard scintillation counter model Tricarb 1900 TR (efficiency $65-67 \%$ ) [23].

\section{Saturation assays}

The uptake of taurine was performed by isotopic dilution experiments with $50 \mathrm{nM}\left[{ }^{3} \mathrm{H}\right]$ taurine and increasing concentrations of taurine from 0.001 to $1 \mathrm{mM}$, and in a preparation of about 250,000 cells per test tube to explore the high and low affinity component of the carrier. The transport was sodium dependent, and 80-90\% inhibited by hypotaurine and beta-alanine $(50 \mu \mathrm{M})$, but not by gamma-aminobutyric acid (GABA). Finally, saturation assays were measured with a concentration of taurine to target the high-affinity taurine uptake $(0.01$ to $1 \mu \mathrm{M})$ [23]. The cell preparation was incubated in the presence of various concentrations of $\left[{ }^{3} \mathrm{H}\right]$ taurine from $0.01,0.025$ and $0.05 \mu \mathrm{M}$, followed by isotopic dilutions with concentrations of taurine from 0.05 to $1 \mu \mathrm{M}$ and $50 \mathrm{nM}\left[{ }^{3} \mathrm{H}\right]$ taurine. The preparation was preincubated at $25^{\circ} \mathrm{C}$ for $2 \mathrm{~min}$ in Ringer solution. Incubation was started by the addition of the substrate. After $5 \mathrm{~min}$ the process was stopped by filtration. The experiments were performed in triplicates.

\section{Effect of zinc ex vivo on $\left[{ }^{3} \mathrm{H}\right]$ taurine transport}

The effect of zinc sulphate $\left(\mathrm{ZnSO}_{4}\right)$ was studied by preincubating the cell preparation with different concentrations of zinc, from 0.001 to $500 \mu \mathrm{M}$. The uptake was initiated by the addition of $50 \mathrm{nM}\left[{ }^{3} \mathrm{H}\right]$ taurine plus $50 \mathrm{nM}$ cold taurine. After $5 \mathrm{~min}$ of incubation at $25^{\circ} \mathrm{C}$, the cells were washed and the process was stopped by filtration. This experiment was done to determine the mean effective concentration $\left(\mathrm{EC}_{50}\right)$ of $\mathrm{ZnSO}_{4}$. The mechanism by which $\mathrm{ZnSO}_{4}$ affects taurine uptake was explored by high affinity $\left[{ }^{3} \mathrm{H}\right]$ taurine uptake in the presence and in the absence of different concentrations of $\mathrm{ZnSO}_{4}(0.1,1,50,100 \mu \mathrm{M})$.

\section{Statistical analysis}

Non-linear fitting was done with the program PRISMA (GraphPad Prism 2). $V_{\max }$ and $K_{\mathrm{s}}$ of taurine transport were calculated either by Lineweaver-Burk plots or by curvilinear analysis. $\mathrm{EC}_{50}$ of $\mathrm{ZnSO}_{4}$ was determined by curvilinear analysis. Each value is expressed as mean \pm standard error of the mean (SEM). The probabilities of the differences among means were derived from the 
analysis of variance (ANOVA), INSTAT 2 program [24]. Significance was considered if $\mathrm{p}<0.05$.

\section{Results}

Cell preparation and incubation time

$\left[{ }^{3} \mathrm{H}\right]$ Taurine uptake was linear respecting the number of cells between 50,000 and 400,000 per tube. For all experiments 250,000 cells were used. The uptake was linear during $10 \mathrm{~min}$ of incubation at $25^{\circ} \mathrm{C}$. The incubation was fixed at $5 \mathrm{~min}$ for the rest of the analysis.

\section{Kinetic parameters of $\left[{ }^{3} \mathrm{H}\right]$ taurine transport}

The analysis of saturation experiments performed in the presence of $50 \mathrm{nM}\left[{ }^{3} \mathrm{H}\right]$ taurine alone and with increasing concentration of non labeled taurine from 0.001 to 1 $\mathrm{mM}$ resulted in a best fitting to a two site model. The kinetic parameters of the high affinity component were $\mathrm{K}_{\mathrm{s} 1}=0.02 \pm 0.003 \mu \mathrm{M}$ and $\mathrm{V}_{\max 1}=34.36 \pm 0.31 \mathrm{fmol} / \mathrm{l} /$ $10^{6}$ cells, and for low affinity component, were $\mathrm{K}_{\mathrm{s} 2}=$ $5.29 \pm 0.110 \mu \mathrm{M}$ and $\mathrm{V}_{\max 2}=55.50 \pm 1.29 \mathrm{fmol} / \mathrm{l} / 10^{6}$ cells. To work with the high affinity component [23], taurine uptake was measured in $0.01-1 \mu \mathrm{M}$ concentration range. The resulting saturation curve was hyperbolic, according to the Michaelis-Menten kinetic model (Figure 1). Data obtained were transformed using the double reciprocal method, producing a linear graph with $\mathrm{R}^{2}=0.94$; this was utilized to determine the kinetic parameters of the transporter, $\mathrm{K}_{\mathrm{s}}=0.03 \pm 0.005 \mu \mathrm{M}$ and $\mathrm{V}_{\max }=38.72 \pm 2.29 \mathrm{fmol} / 10^{6}$ cells.

\section{Effect of zinc on $\left[{ }^{3} \mathrm{H}\right]$ taurine transport}

The simultaneous incubation of cell preparation with $\mathrm{ZnSO}_{4}$ in concentrations ranging from 0.001 to $500 \mu \mathrm{M}$ reduced the uptake with an $\mathrm{EC}_{50}=0.72 \pm 0.013 \mu \mathrm{M}$ (Figure 2). The mechanism by which the zinc affected

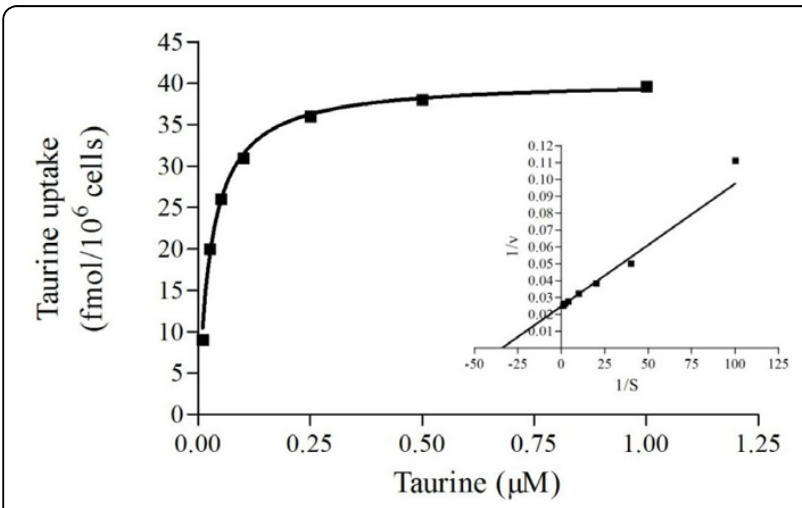

Figure 1 Representative curve of the saturation of $\left[{ }^{3} \mathrm{H}\right]$ taurine uptake into goldfish retinal cells determined by isotopic dilution. Data are best fitted to a rectangular hyperbola $\mathrm{R}^{2}=0.96$. The insert correspond to Lineweaver-Burk analysis of the same results, $R^{2}=0.98$.

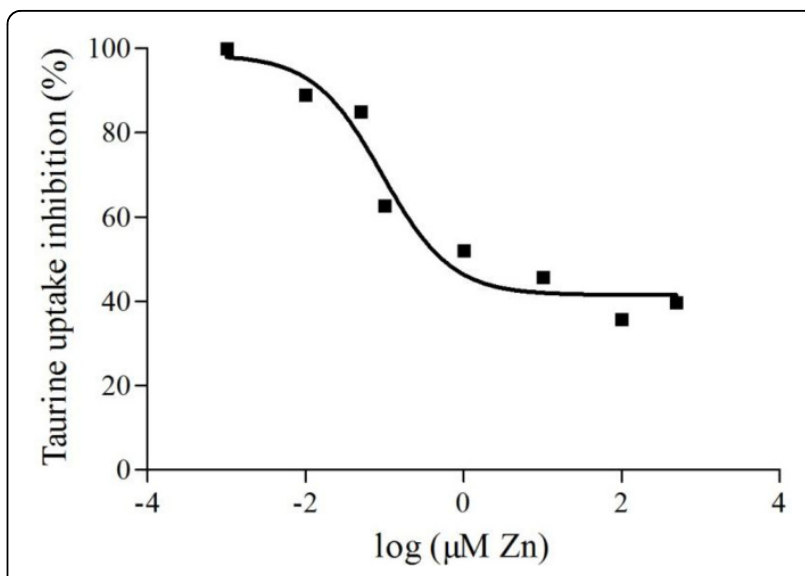

Figure 2 Representative curve of the zinc inhibition on $\left[{ }^{3} \mathrm{H}\right]$ taurine uptake (\%) in goldfish retinal cells.

high affinity $\left[{ }^{3} \mathrm{H}\right]$ taurine uptake was explored, at a zinc concentration of $100 \mu \mathrm{M}$, a $30 \%$ reduction in taurine transport capacity was observed, $\mathrm{V}_{\max }=30.58 \pm 2.10$ $\mathrm{fmol} / 10^{6}$ cells, compared to the control group, $\mathrm{V}_{\max }=$ $39.72 \pm 2.02 \mathrm{fmol} / 10^{6}$ cells. At concentrations of $0.1,1$ and $50 \mu \mathrm{M}$ of zinc there were no significant modifications in either the $V_{\max }$ or $K_{\mathrm{s}}$ of taurine transport as compared to the control group (Figure 3).

\section{Discussion}

\section{Effect of zinc on taurine transport in isolated cells from goldfish retina}

Taurine transport in isolated cells from goldfish retina presented two components, one of high and another of low affinity, results that agree with those obtained by Guerra et al.[23] and Lima et al. [25]. The presence of two components of taurine transport, high and low affinity, has been demonstrated in cells isolated from rat retinas [4], in pigment epithelial cells from both rats [26] and humans [27], and in human lymphocytes [28]. In the present study, zinc caused a noncompetitive inhibition of high affinity taurine transport, with an $\mathrm{EC}_{50}=$ $0.072 \mu \mathrm{M}$. Taurine transport inhibition did not reach $50 \%$ with the concentrations used, probably reflecting the variable sensitivity of the components or the limited sites of zinc for exerting its effect. It might be that higher concentrations of zinc are needed to cause a greater inhibition, although the shape of the curve showed a flatness at the higher concentrations tested. It may also be that greater inhibition was not observed because zinc affects only one of the taurine transporters, TAUT-1 or TAUT-2, and the unaffected transporter maintains the uptake. The mechanism by which zinc affects taurine transport has not been demonstrated. There may be a binding of zinc in the transporter that affects union or translocation of taurine, or possibly the formation of taurine-zinc complexes, rather than free 

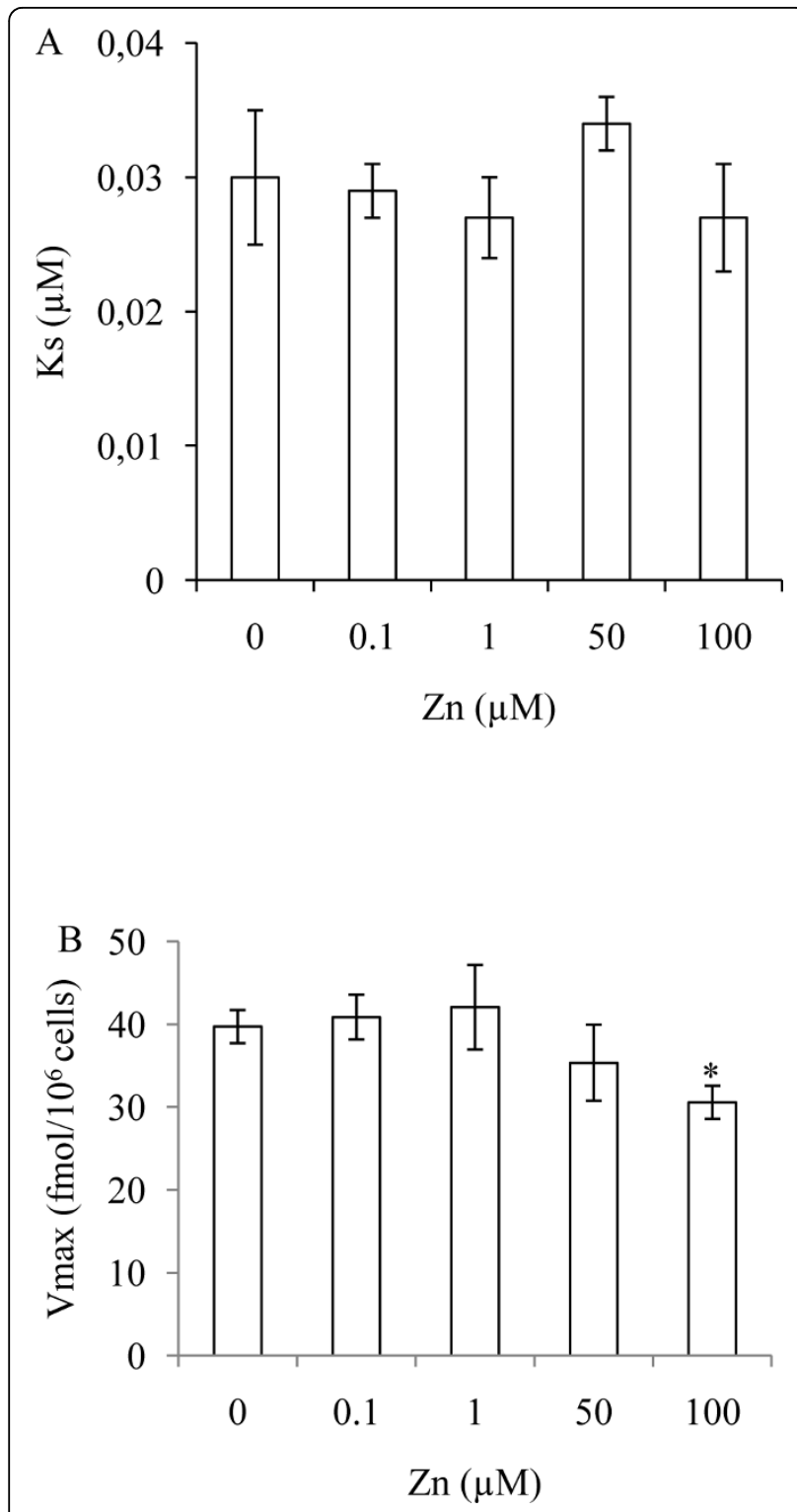

Figure 3 Saturation experiments of high affinity of $\left[{ }^{3} \mathrm{H}\right]$ taurine uptake, $\mathrm{Ks}(\mathrm{A})$ and $\mathrm{Vmax}(\mathrm{B})$, in the presence of variable concentrations of zinc. Each value is the mean $\pm S E M, n=3 .{ }^{*} p$ $<0,05$ with respect to control.

zinc could modulate the operation of the transporter. In fact, taurine, taurine transporter TAUT-1, and zinc coexist in ganglionic cells and in photoreceptors of goldfish and rat retinas [29].

Recent work has demonstrated that zinc also modulates $\mathrm{Na}^{+} / \mathrm{Cl}^{-}$-dependent neurotransmitter transporters, such as those of monoamines $[19,20]$ and other neurotransmitter transporters as glutamate, histamine and gamma-aminobutyric acid (GABA) [30-32]. Most of these studies coincide in that the effect of zinc, whether stimulation or inhibition, is produced directly on the transporter. Zinc enhances the binding of cocaine analogues to dopamine transporter, and behaves as a noncompetitive inhibitor of dopamine transport in synaptosomal membranes, $10 \mu \mathrm{M}$ zinc inhibits $\mathrm{V}_{\max }$ by $30 \%$ and $1 \mathrm{mM}$ by $50 \%$ ), an effect due to the union of zinc in an area of the transporter that affects the translocation of the monoamine [33]. Residues of the proteins that interact with zinc, $\mathrm{His}^{193}, \mathrm{His}^{375}$, and $\mathrm{Glu}^{396}$, which are close to one another, have been recognized in the tertiary structure of this transporter, and zinc facilitates the formation of oligomeric complexes of the transporter that affect the process of translocation of the neurotransmitter $[21,34,35]$.

It has also been reported that zinc inhibits the transport of glutamate in Müller cells and retinal cones of salamanders with an $\mathrm{IC}_{50}=0.84 \mu \mathrm{M}$ [36]. The effect of zinc was rapid and irreversible, which suggests a direct effect on the inhibition of transport, but the ion does not compete for the binding sites of glutamate, sodium, potassium or for transporter protons, but instead binds to an external point to the membrane, which implies an allosteric modulation transporter function [36]. Glutamate EAAT1 transporter expressed in oocytes of Xenopus laevis is inhibited by zinc, with an $\mathrm{IC}_{50}=9.9 \mu \mathrm{M}$, and on the basis of studies by site-directed mutagenesis it has been reported that $\mathrm{His}^{146}$ and $\mathrm{His}^{156}$ residues of EAATI form part of the binding sites of zinc. These residues are found on the extracellular edge of the third transmembrane domain. Zinc bond alters the shape of this region, which reconstructs the contour of the pore, thus regulating the passage of the substrate and ions through the transporter [30].

Zinc reduced taurine transport in goldfish retinas with an $\mathrm{EC}_{50}=0.072 \mu \mathrm{M}$. An ample range of effective concentrations of zinc has been reported regarding its effect on voltage-dependent calcium channels, with an $\mathrm{IC}_{50}=$ $69 \mu \mathrm{M}$, for all dopamine and glutamate transporters, with an $\mathrm{EC}_{50}=0.79$ and $0.84 \mu \mathrm{M}$ respectively, and for $N$-methyl $D$-aspartate (NMDA) and GABA receptors, with $\mathrm{EC}_{50}$ of $0.1-100 \mu \mathrm{M}$ and $0.6-320 \mu \mathrm{M}$ respectively [17,33,36-38]. The concentration of extracellular zinc estimated in the brain at rest is 10 to $20 \mathrm{nM}$ [39]; however, the concentration of total zinc in goldfish retina is $413 \mathrm{nM}$ [40], and under these conditions zinc does not affect taurine transport rate. As well as in other areas of the CNS, the labile zinc of the retina is released during neuronal activity, although it is possible that taurine transport could be inhibited when there is an excess of extracellular zinc, resulting in neurodegeneration. Culture retinal cells exposed to $300-500 \mu \mathrm{M}$ of zinc during 15 min results in significant neuronal death [41].

The trophic effect of taurine is inhibited by $\mu \mathrm{M}$ concentrations of zinc in cultures of goldfish retinal explants [16]. In addition, taurine does not counteract the inhibitory effect of $1 \mu \mathrm{M}$ zinc [16], which may be 
due to inhibition of taurine transport. This conclusion is consistent with the fact that the trophic effect of the taurine is dependent on its intracellular levels $[42,43]$. Zinc deficiency alters taurine levels in goldfish retina, its trophic effect and increases taurine uptake [40]. Zinc ex vivo and zinc deficiency have different effects on taurine transport, and the mechanisms on this transport remain to be clarified.

\section{Conclusions}

Zinc reduced taurine transport capacity and noncompetitively inhibited it. The mechanism by which zinc affects taurine transport is unknown at the present. There may be a binding site of zinc in the transporter that affects the union or the translocation of taurine, or probably the formation of taurine-zinc complexes, rather than free zinc, modulates the operation of the transporter.

\section{Abbreviations}

Mean effective concentrations $\left(\mathrm{EC}_{50}\right)$, Constant affinity (Ks), Max capacity (Vmax), standard error of the mean (SEM) and taurine transporter (TAUT).

\section{Acknowledgements}

This work was supported by Grant S1-2001-903 from Fondo Nacional de Investigación, Tecnología e Innovación (FONACIT), Venezuela. S. Nusetti was a PhD Student of Centro de Estudios Avanzados, Instituto Venezolano de Investigaciones Científicas, with financial support from Universidad de Oriente and FONACIT. S. Nusetti is a Professor at Universidad de Oriente her new address is Postgrado de Biología Aplicada, Cerro del Medio, Núcleo de Sucre, Universidad de Oriente, Cumaná, Venezuela.

This article has been published as part as part of Journal of Biomedical Science Volume 17 Supplement 1, 2010: Proceedings of the 17th International Meeting of Taurine. The full contents of the supplement are available online at http://www.jbiomedsci.com/supplements/17/S1.

\section{Authors' contributions}

SN discussed the design, carried out the experiments, made calculations, participated in the discussion of results, and did most of the writing. MU actively participated in transport experiments, in standardizing conditions, commenting results, and in sustaining the basic facilities for performing accurate experiments. $L \mathrm{~L}$ is the Grant recipient, made the contribution for conception, design, and analysis, interpretation of data, discussion, and final writing.

\section{Competing interests}

The authors have non-financial competing interests in an exclusive academic way.

Published: 24 August 2010

\section{References}

1. Militante JD, Lombardini JB: Taurine: evidence of physiological function in the retina. Nutr Neurosci 2002, 5:75-90.

2. van Gelder N: A central mechanism of action for taurine: osmoregulation, bivalent cations, and excitation threshold. Neurochem Res 1983, 8:687-699.

3. Lima L: Taurine and its trophic effects in the retina. Neurochem Res 1999, 24:1333-1338.

4. Militante J, Lombardini J: Taurine uptake activity in the rat retina: protein kinase C-independent inhibition by chelerythrine. Brain Res 1999, 818:368-74.

5. Ahn Y, Kim Y, Hong S, Koh Y: Depletion of intracellular zinc induces protein synthesis-dependent neuronal apoptosis in mouse cortical culture. Exp Neurol 1998, 154:47-56.
6. Vallee B, Falcchuk K: The biochemical basis of zinc physiology. Physiol Rev 1993, 73:79-105.

7. Ugarte M, Osborn N: Zinc in the retina. Prog. Neurobiol 2001, 64:219-249.

8. Pasantes-Morales $\mathrm{H}, \mathrm{Cruz} \mathrm{C}$ : Protective effect of taurine and zinc on peroxidation induced damage in photoreceptor outer segments. $J$. Neurosci Res 1984, 11:303-311.

9. Grahn B, Paterson P, Gottschall-Pass K, Zhang Z: Zinc and the eye. J Am Coll Nutr 2001, 20:106-118.

10. Oteiza P, Hurley L, Lonnerdal B, Keen C: Effects of zinc deficiency on microtubule polymerization in the developing rat brain. Biol Trace Elem Res 1990, 24:13-23.

11. Huaqing $G$, Amemiya $T$ : Optic nerve changes in zinc-deficient rats. Exp Eye Res 2001, 72(z):363-369.

12. Lees G, Lehmann A, Sandberg M, Hamberger A: The neurotoxicity of zinc in the rat hippocampus. Neurosci Lett 1990, 120:155-158.

13. Chai F, Truong-Tran A, Ho L, Zalewski D: Regulation of caspase activation and apoptosis by cellular zinc fluxes and zinc deprivation. Immunol Cell Biol 1999, 77:272-278.

14. Weiss J, Sensi S, Koh J: $\mathrm{Zn}^{2+}$ a novel mediator of neural injury in brain disease. Trends Pharm Sc 2000, 21:395-401.

15. Sandstead HH, Frederickson CJ, Penland JG: History of zinc as related to brain function. J Nutr 2000, 130(2S Suppl):496S-502S.

16. Nusetti S, Obregon F, Quintal M, Benzo Z, Lima L: Taurine and zinc modulate outgrowth from goldfish retinal explants. Neurochem Res 2005, 30:1483-1492.

17. Harrison N, Gibbons S: $\mathrm{Zn}^{+2}$ : an endogenous modulator of ligand and voltage-gated ion channels. Neuropharmacology 1994, 33:935-952.

18. Schetz J, Chu A, Sibley D: Zinc modulates antagonist interactions with $\mathrm{D}_{2}$-like dopamine receptors through distinct molecular mechanisms. J Pharmacol Exp Ther 1999, 289:956-964.

19. Scholze $P$, Norregaard L, Singer E, Freissmuth M, Gether U, Sitte $H$ : The role of zinc ions in reverse transport mediated by monoamine transporters. J Biol Chem 2002, 277:21505-21513.

20. García-Colunga J, Reyes-Haro D, Godoy-García IU, Miledi R: Zinc modulation of serotonin uptake in the adult rat corpus callosum. $J$ Neurosci Res 2005, 80:145-149.

21. Giros B, Caron M: Molecular characterization of the dopamine transporter. Trends Pharmacol Sci 1993, 14:43-49.

22. Lima L, Cubillos $S$, Guerra A: Regulation of high affinity taurine transport in goldfish and rat retinal cells. Adv Exp Med. Biol 2000, 483:431-440.

23. Guerra A, Urbina M, Lima L: Modulation of taurine uptake in the goldfish retina and axonal transport to the tectum. Effect of optic crush and axotomy. Amino Acids 2000, 19:1-17.

24. Tapia F: GraphPad Instat Softward. 1994, V2.05a.

25. Lima L, Matus P, Drujan B: Differential taurine uptake in central and peripheral regions of goldfish retina. J Neurosci Res 1991, 28:422-427.

26. Salceda R, Saldaña M: Glutamate and taurine uptake by retinal pigment epitelium during rat development. Comp Biochem Physiol C 1993, 104:311-316.

27. Grafe F, Wohlrad W, Neubert R, Brandsch M: Functional characterization of sodium-and chloride-dependent taurine transport in human keratinocytes. Eur J Pharm Biopharm 2004, 57:337-341.

28. Fazzino F, Urbina M, Mata S, Lima L: Taurine transporter in lymphocytes of major depression patients. Adv Exp Med Biol 2006, 583:423-426.

29. Nusetti S, Salazar V, Lima L: Localization of taurine transporter, taurine and zinc in goldfish retina. Adv Exp Med Biol 2009, 643:233-240.

30. Vanderberg R, Mitrovic D, Johnston R: Molecular basis for differential inhibition of glutamate transporter subtypes by zinc ions. Mol Pharmacol 1998, 54:189-196.

31. Huszti Z, Horvath-Sziklai A, Noszal B, Madarasz E, Deli A: Enhancing effect of zinc on astroglial and cerebral endothelial histamine uptake. Biochem Pharmacol 2001, 62:1491-1500.

32. Wu Q, Wada M, Shimada A, Yamamoto A, Fujita T: Funcional characterization of $\mathrm{Zn}^{2(+)}$ - sensitive GABA transporter expressed in primary cultures of astrocytes from rat cerebral cortex. Brain Res 2006, 1075:100-109.

33. Norregaard L, Frederiksen D, Nielsen E, Gether U: Delineation of an endogenous zinc-binding site in the human dopamine transporter. EMBO J 1998, 17:4266-4273.

34. Loland C, Norregaard L, Gether U: Defining proximity relationships in the tertiary structure of the dopamine transporter. Identification of a 
conserved glutamic acid as a third coordinate in the endogenous $\mathrm{Zn21-}$ binding site. J Biol Chem 1999, 274:36928-36934.

35. Norgaard-Nielsen K, Norregaard L, Hastrup H, Javitch J, Gether U: $\mathrm{Zn}^{2+}$ site engineering at the oligomeric interface of the dopamine transporter. FEBS Letters 2002, 524:87-91.

36. Spiridon M, Kamm D, Billups B, Mobbs P, Attwell D: Modulation by zinc of the glutamate transporters in glial cells and cones isolated from the tiger salamander retina. J Physiol 1998, 506:363-376.

37. Kaneda M, Andrásfalvy B, Kaneko A: Modulation by $\mathrm{Zn}^{+2}$ of GABA responses in bipolar cells of the mouse retina. Vis Neurosci 2000, 17:273-281.

38. Kaneda M, Ishii K, Akagi T, Tatsukawa T, Hashikawa T: Endogenous zinc can be a modulator of glycinergic signaling pathway in the rat retina. $J \mathrm{Mol}$ Histol 2005, 36:179-85.

39. Takeda A: Zinc homeostasis and functions in the brain. Biometals 2001, 14:343-351.

40. Nusetti S, Urbina M, Obregon F, Quintal M, Benzo Z, Lima L: Effects of zinc ex vivo and intracellular zinc chelator in vivo on taurine uptake in goldfish retina. Amino Acids 2010, 38:1429-1437.

41. Yoo MH, Lee JY, Lee SE, Koh JY, Yoon YH: Protection by piruvate of rat retinal cells against zinc toxicity in vitro, and pressure-induced ischemia in vivo. Invest Ophthalmol Vis Sci 2004, 45:1523-1530.

42. Lima L, Cubillos S: Taurine might be acting as a trophic factor in the retina by modulating phosphorilation of cellular proteins. J Neurosci Res 1998, 53:377-384.

43. González-Quevedo A, Obregón F, Urbina M, Roussó T, Lima L: Effects of taurine deficiency and chronic methanol administration on rat retina, optic nerve and brain amino acids and monoamines. Nutr Neurosci 2003, 6:253-261.

doi:10.1186/1423-0127-17-S1-S13

Cite this article as: Nusetti et al.: Effects of zinc ex vivo on taurine uptake in goldfish retinal cells. Journal of Biomedical Science 201017 (Suppl 1):S13.

\section{Submit your next manuscript to BioMed Central and take full advantage of:}

- Convenient online submission

- Thorough peer review

- No space constraints or color figure charges

- Immediate publication on acceptance

- Inclusion in PubMed, CAS, Scopus and Google Scholar

- Research which is freely available for redistribution

Submit your manuscript at www.biomedcentral.com/submit 